\title{
Research on Incentive Mechanism of Market Subject in New Energy Development
}

\author{
Yi-Ke YANG \\ North China Electric Power University, Beijing Changping District Beinong Road No. 2. \\ echoyang111@foxmail.com
}

Keywords: Newenergy, Market subject, Incentives.

\begin{abstract}
The author precisely analysis from the four aspects of how the market players to establish a good incentive mechanism to promote the rapid development of new energy. Researching and introducing what is incentive theory, mechanism design theory, and their use in the development of new energy. Then finding the significance of the development of new sources and the existing problems like absence of system construction, policy bias, unbalanced management and so on. This paper studies the main form, the important significance and the different market players to promote the development of new energy load, by studying from the incentive mechanism to the relevant cutting-edge issues to find domestic and foreign new energy development market incentives in the main means, which is the domestic market development of new energy incentive mechanism research. Finally putting forward problems and looking for Chinese new energy development which will have practical significance.
\end{abstract}

\section{Related Theory and Application}

Incentive Theory. Motivation is an activity that strengthens, guides, and sustains an activity or process by stimulating an intrinsic motivation, and then influencing people's inner needs. Motivation can be divided into positive and negative incentives. Positive motivation refers to the fact that when a person's behavior is consistent with social needs and organizational goals through the recognition and reward to maintain and consolidate this behavior, which more fully mobilize the enthusiasm of members. Negative motivation means that when a behavior does not meet the needs of the community or organizational goals through criticism and punishment to suppress this behavior and make it no longer occur, while guiding the enthusiasm of the organization's members to move in the right direction. Incentive theory is divided into process-based incentive theory, content-based incentive theory and incentive enhancement theory.[1]

Mechanism Design Theory. Good economic mechanisms must be able to meet three requirements: first, it can achieve efficient use and allocation of resources; second, mechanisms run with the lowest possible cost information; third, mechanisms can coordinate the interests of participants to reach agreement. The theory of economic mechanism design combines the social abandonment theory and social choice theory, which belongs to the branch of institutional economics. It is in a given social goals or economic objectives under the premise of the freedom to choose, as well as voluntary exchange. Under the constraints of information incompletely and other decentralized decision-making parameters and through the incentive and the minimum cost of the flow of private information to ensure that the interests of institutional participants and institutional designers obtain the economic mechanism information which has consistent interest. And finally realize the social resource allocation has Pareto effect.[2]

The Application of Incentive Theory in the Study of the Main Motivation Mechanism of New Energy Development Market. Incentive theory argues that the cooperation between members of the organization is often destroyed by the opportunistic behavior of some members, and the establishment of appropriate incentives can mitigate such undesirable behavior. Incentive theory regards the organization as a node that links different individuals, believing that the organizational elements of bounded rationality are risk aversion, selfishness, and the organization is often in a state of disagreement. In the practice of using the incentive theory to guide the research on the incentive 
mechanism of the main new energy development market, the motivations and behaviors of the subjects can be fully understood from the incentive theory, and whether there are differences between the target and the asymmetry of the information There is interaction and influence.

\section{The Importance of New Energy Development in China}

Protect the National Energy Security, Enhance International Competitiveness. With the growth of the world economy, the world's total energy consumption continues to grow. In 2012 global energy consumption growth, more than $75 \%$ growth from China, and this pattern can't be reversed in a short term, and energy gap will gradually expand. Relying on conventional energy will not be able to meet the needs of economic development. By 2020, the new energy will be duty-bound to bear the burden of supply to make China's energy supply gap up. Clean and sustainable new energy will consolidate China's energy security foundation and reduce the external dependence of China's energy. It will put the new power into the traditional energy industry andbuild a moderately prosperous society to provide new strength for China.[3]

Protect the Ecological Environment, and Promote the "Resource-Saving and Environment-Friendly" Social Construction. The extensive use of fossil fuels has caused serious environmental and ecological problems. First, the widespread use of fossil fuels that are being produced has caused serious environmental pollution problems. Coal oxide produced by the formation of acid rain. Under certain conditions, following the Nordic, North America, China has become the world's third largest acid rain country, nearly $62 \%$ of the southern city take acid rain. Sulfur dioxide pollution poses a serious threat to our natural resources, ecosystems and public health, resulting in huge economic losses that have seriously affected the national economy and people's normal lives. Second, a large number use of oil, coal and other traditional energy resulting in carbon dioxide, nitrogen oxides and other greenhouse gas emissions. Promoting new energy actively can significantly reduce environmental pollution, while at the same time reducing greenhouse gas emissions and making due contributions to mitigating global climate will change and building a good international image.

Promote The Optimization and Upgrading of Industrial Structure, Adjust the Economic Structure. Its related to the overall national economy strategic task that to adhere to the new road to industrialization, promote the industrial structure to upgrade the steady progress, and accelerate the optimization and adjustment of economic structure. The new energy industry is in line with the requirements of green GDP, high technology content and broad market prospect. It has the advantages of low resource consumption, high cleanliness, high potential market, good comprehensive benefit and so on. Its development is related to energy security, economic security, ecological security, which is a emerging industry with high growth and good economic efficiency. It is expected to lead the global economy into the next round of economic growth cycle of the important driving force.[4]

Promote the Increase of Farmers' Income and Promote the Construction of New Socialist Countryside. Biomass energy and other new energy development will promote the new rural construction effectively. On the one hand, the development of new energy will promote energy in rural areas to meet the energy needs. Wind energy complementary and independent photovoltaic power generation will help to solve the power supply in remote areas and biogas and small hydropower for rural areas to provide clean energy. On the other hand, it will help farmers increase their income by biomass energy development, extension of the agricultural industry chain, rural biomass energy converted into commodity energy.

\section{China 's New Energy Development Problems}

New Energy Development System Construction Absence. Being lack of sound and operational laws, long-term, systematic and unified energy strategies, as well as new energy industry organizations are serious. At the same time, the supply and demand of new energy market is uneven, 
China's new energy consumption depends on the international market so much, due to the lack of a stable domestic market to meet consumer demand. Energy price policy drawbacks, the implementation of price control policies, not only makes the government under financial pressure, but also inhibits the energy saving of consumers and businesses.

The Bias of New Energy Development of Fiscal Policy and Tax Policy. Financial tax policy system is not strong, China's current policy is seriously lagging behind and lack of unity. Fiscal policy support is unclear and there is no policy support program. Fiscal policy incentives are small. Value-added tax is not strong, tariff regulation is not balanced, and has not yet developed a unified national new energy enterprise income tax or other preferential tax policies.[5]

China's New Energy Technology is Lack of Motivation. New energy technology policy, laws and regulations are not perfect, the new energy technology innovation system is incomplete and the new energy technology R \& D ability is weak, the overall level is low and the innovation ability is insufficient, which causes our country energy technology backward, the use efficiency is low, the consumption structure is unreasonable and the environmental pollution seriously. Backward technology is the main factor which restricts the development of new energy in China. ${ }^{[6]}$

Unbalanced Development. China's new energy development is mainly reflected in the uneven three aspects:

Unbalanced Industrial Chain. The new energy industry from the upstream technology and equipment, production links to the application of output, should form a reasonable whole industry chain.

Unbalanced Investment. From the overall situation, a lot of money put into the field of wind energy and solar energy, but tap the biomass energy. Nuclear power ratio is low, geothermal, tidal, biogas and other energy fields are less, new energy development strategy awareness are limited.

Urban and Rural Inequality. New energy applications in rural areas are less.

Industry Management is Loose. The standard system and construction of talents are seriously lagging behind. The lack of communication channels and communication platforms between enterprises. It has caused the phenomenon of enterprises to compete and even vicious competition. The lack of technical standards and the shortage of talents are becoming more and more prominent.

Rigid Grid System. China's new energy conversion costs are very high, and power grid are difficult. ${ }^{[7]}$

\section{China 's New Energy Development Market Incentives.}

The Construction of Incentive Mechanism of Market. Government, enterprises and the public are the main body in the development of new energy market in China, the development of new energy needs this multi-compound's main efforts and support.

As a central and local administrative organ of a country, the government mainly expresses the will of the state, issues orders and deals with affairs. It is an indispensable institutional factor in economic and social development and plays an important role in the process of national economic and social development.

Enterprise is engaged in the production, circulation, services and other economic activities to produce or service to meet the needs of the community, the implementation of independent management, independent accounting, it always set up a profitable economic organization according to the law.

The public refers to individuals, groups, and organizations that have a direct or indirect relationship with an organization or group, and they have more or less realistic or potential interests or influence in the organization's goals, persistence, and development. 
The Central Government's Multi - Target Incentives for Local Governments and Departments. In the process of developing new energy, the central government not only entrusts the local government to be responsible for the economic growth and economic efficiency of the region, but also entrusts the local government to carry out environmental management and environmental benefits. The central government can take the following ways to encourage local governments in the development of the economy while achieving environmental growth.

Enact Laws. Develop laws and regulations related to the development of new energy sources and clarify the rights and obligations of local governments to promote the effective integration of new energy and various industries. Many countries ensure that new energy plans are implemented through laws and regulations. Such as Japan's energy law not only puts forward a stable supply that is suitable for environmental and market principles of energy policy orientation, but also clearly stipulates the responsibility of the state, local public organizations, institutions and national responsibilities.[8]

The Principle of Appropriateness. The relevant departments of the state should be guided and mandatory documents at the same time, all levels of government in the establishment of sound and new energy-related system need to be appropriate. Relevant industrial sectors should be combined with China's new energy development planning objectives and the overall trend, adjusting industrial development model timely. At the same time, the developing and establishing a complete new energy technology and equipment manufacturing system.[9]

Establish an Assessment System. To establish a suitable system for China's national conditions of the new energy development and evaluation index, and the evaluation of indicators should be put into the local economic accounting system and the performance of government officials' assessment.

Government - Related Measures for the Development of New Energy Companies. China's the biggest responsibility of new energy development is the government, as well as the implementation of the main business. Therefore, the establishment of new energy funds security system through the implementation of new energy cost sharing system to address the constraints of new energy development market constraints. At present, China should change the direction from the government investment, capital subsidies, tax incentives and other aspects of the market to actively.

Tax Policy. Tax incentives include VAT reductions, customs duties and income taxes. Improving the value of China's new energy tax can reduce the value-added tax rate of new energy companies to ease the calculation of value-added tax which can't be deductible or less deductible due to the supply of new energy companies' production which have a larger proportion in the cost of value-added tax. Reasonable use of tariffs to guide the development of new energy sources can reduce the cost of new energy equipment to promote the sustainable development of new energy companies. To promote the development of new energy industry, but also increase the income tax on new energy companies tax incentives, such as: the actual implementation of new energy companies' R \& D expenses, deducted to buy new energy products, the cost of part of the enterprise income tax credit.

Fiscal Policy. The central government for the new energy industry mainly on technology research and development and demonstration projects for financial subsidies. Local governments for wind energy and solar power promote financial subsidies. Rational use of financial discounts, the appropriate use of "government procurement" policy ensure that the new energy green products priority to the right to mobilize the purchasing power of enterprises and institutions and reduce the financial burden of the government. In the new energy and renewable energy development of the producer subsidies, which is conducive to reducing production costs, increase equipment production, thereby enhancing business efficiency. Investor subsidies are directly subsidized by new energy and renewable energy project developers. The advantage of investor subsidies is to mobilize the enthusiasm of investors, increase the renewable energy production capacity, expand the scale of renewable energy industry. Consumer subsidy is a direct subsidy for renewable energy 
products.[10]

Diversified and Innovative Financing Model. New energy is a strategic resource of country, the initial cost of investment is high, only companies' strength is difficult to sustain. In addition to government support and traditional market financing channels, there have been many new financing models (such as attracting venture capital funds, green certificate plans, carbon trading mechanism, etc.). In the case of carbon emissions licensing transactions, the global total of $\$ 50.393$ billion in 2007, the next 20 years, a global carbon trading market will grow to the total size of $\$ 3$ trillion.[11]

The Government's Incentive to the Public's Hierarchy. The public can reduce consumption activities on the use of non-renewable resources in the field of consumption, purchase and consumption in line with new energy low-carbon standard products or services to minimize energy consumption, and reduce pollution and waste. The consumption can also create a sustainable market demand for the formation which the interests of producers driven, forcing the production to shift to resource conservation, environment-friendly mode of operation, more production of new energy.

Public Investment in the Development of New Energy Incentives. New energy is in the rise stage, investment requires a lot of money, if only by the government investment, the cost is huge, therefore, the new energy industry investment should distinguish between government investment and private investment. Private investment should be the main body, but the government also strengthen the guidance, like regulating private investment behavior, putting an end to the malignant enclosure, blinding expansion, to achieve the healthy development of new energy industry and a reasonable regional division of labor.[12]

New Energy Industry Technology Policy. Technology research is the fundamental way of industrialization of new energy and renewable energy to make great progress. Establishing long-term development vision, taking the real interests into account, increasing investment in scientific research, and accelerating the industrialization of technology to walk out of a road with independent innovation with Chinese characteristics, which in order to improve the international competitiveness of the industry. Technology research and development and industrialization of new energy and renewable energy has made great progress in the development of the fundamental way. Some countries have set up special national renewable energy agencies, which are unified organization and coordination of the country's renewable energy development to promote technology research and development and industrialization process. Denmark has invested more than 2 billion euros to support research institutions and enterprises for the development of wind power manufacturing technology. Only occupied the high ground of renewable energy development technology, it will be possible to promote the industrialization of the development process.[13]

International Competition and Cooperation Strategy. First, promote exchanges between countries and strategic mutual trust, and guide the promotion of industrial factors. Second learn from foreign management experience, to meet the needs of industrial public services. Third use the international market trading standards, establish a new order to regulate the international market. Changes in the world's major economic forces determine it in the international market order. In this process, it is a government's responsibility lies, but also its active pursuit of the goal to familiar and use the existing international market trading standards to serve the country's industrial transactions. Forth, gradually establish a new energy foreign policy. China should deepen and accelerate the resource diplomacy as soon as possible to get rid of energy shortages and energy dependence so that energy diplomacy has become an important means of national strategy to achieve global resources, while focusing on new energy development to maintain energy security is relatively independent.

\section{Summary}

New energy refers to the new technology as the basis, and the system's development and utilization of energy, with clean, renewable, flexible and applicable and a series of advantages, while facing the large cost of development and utilization, higher safety standards. China's new energy industry 
started lately and has a large energy consumption, whose fossil energy has been unable to meet the growing economic needs. It has the development of new energy rich resources and a certain industrial base, recent years, the rapid development of new energy industry, some new energy's use technology has reached the level of commercialization. From resource, technology and industry point of view, China has energy model to develop new energy and strong support, therefore the new energy industry showed a good momentum of development. In the future energy structure, the new energy will play an important role in the excellent energy, which can protect the ecological environment, protect the energy supply, promote economic and social sustainable development. Building a harmonious low-carbon society has important significance, but because of technology, system, policy and other reasons, there is still a long way to go, the future development of new energy will be a road full of opportunities and challenges Therefore, under the guidance of the main market, we need to optimize the energy structure, absorb and digest foreign advanced technology. Developing a series of good new energy development policies and other aspects of efforts to promote sound can develop new energy industry rapidly.

\section{References}

[1] Liao-GANG HAO, Jian-Xi LIU. The New Trend of Incentive Theory Research[J]. Journal of Beijing Technology and Business University, 2003 (9).(in Chinese)

[2] Li-Ping FU, A Study on the Incentive Mechanism of the Behavioral Motivation of Developing Low - carbon Economy in China, 2012.12(in Chinese)

[3] Hai-Long ZHANG. China Energy Development Research, 2014(12) P.14(in Chinese)

[4] Xue-Jie LIU, Chang-Hong LI, China 's New Energy Industry Development Strategy Positioning, Policy Framework and Government Role. China Administration, 2014(3) (in Chinese)

[5] Hai-Long ZHANG. China Energy Development Research, 2014(12) P.87(in Chinese)

[6] Shu-Feng LI, Uncertainty, Government Incentive Mechanism and Renewable Energy Technology Progress[J].Science and Technology Progress and Countermeasures, 2009(3) P.89(in Chinese)

[7] Dong-Ming REN, China 's New Energy Industry Development and Institutional Innovation. Chinese and Foreign Energy, 2011(1) P.34(in Chinese)

[8]National Development and Reform Commission Energy Research Institute. Drawing Lessons from Foreign Experience and Promoting the Development of Renewable Energy in China through Legislative Means.[R]. Beijing: National Development and Reform Commission Energy Research Institute, 2006. (in Chinese)

[9] Hai-Long ZHANG. China Energy Development Research, 2014(12) P.147(in Chinese)

[10] Xian-Chang ZHANG. Research on the Development Policy of China 's New Energy Industry, 2014.6(in Chinese)

\section{[11]WorldBank.StateandTrendsoftheCarbonMarket2008[EB/OL].}

[12] Hou-Kai WEI, to Treat the Market as the Main Body, to Promote the Development of New Energy Industry: Energy industry development and private investment, P21 (in Chinese)

[13] Meng-Yuan YAO, Research on China 's New Energy and Renewable Energy Development Policy, 2011(3) (in Chinese) 